\title{
СИСТЕМСКА СЕМЕЈНА ТЕРАПИЈА ВО РАБОТА СО КОРИСНИЦИ НА НАРКОТИЧНИ СРЕДСТВА
}

\section{Кратка содржина}

По долгогодишни медицински истражувань, јасно е дека зависноста од дроги е сложено мултифакторско биолошко и нарушено однесуване. Научните достигнувать овозможуваат развиване на третмани кои го помагаат нормализиратьето на функцииониратето на мозокот на засегнатите лица и ги подржжуваат во менуваюето на нивното однесуванее. Нудеюето третмани врз основа на научни докази сега им помага на милиони засегнати лица да ја вратат контролата врз нивните животи. Токму психосоцијалната работа со овие лица пружа вакви методи кои во соработка со зависникот кој секако мора да биде подготвен на овој вид соработка може да продуцииаат ефекти позитивни и за него и за средината вкхучувајки го и семејството кое секогаш е најзасегнато од зависничкиот проблем.

Овој труд обработува дел од тие методи, односно системска семејна терапија која би овозможила прогрес во однесуватьето на зависникот, неговата желба за промена во однесуването односно третмани за лечете и превенциија од релапс и рецивидно однесуваюе. Целата таа композиција на психосоцијална работа, работа преку семејните терапии, и контрола над зависникот овозможено и потпомогнато од официјалните здравствени и граѓански асоццијацции придонесуваат за оформуване на цеелокупна стратегија за помош на зависниците и намахуване на бројот на зависници во државата.

\section{Клучни зборови: СИСТЕМСКА СЕМЕЈНА ТЕРАПИЈА, ТРЕТМАН, ЗАВИСНИЦИ}

Семејната динамика драстично се промени во последните неколку децении, влијаејќи на начинот на кој тече животот, како и на однесувањето и улогите што ги има семејството. Модерната семејна единица може да вклучува семејства со еден родител, зголемени стапки на разводи, бракови на хомосексуалци. Без оглед на раздичните начини на промена на семејната единица, семејната терапија сѐ уште е корисна компонента на третманот со здоупотреба на супстанции. Всушност, истражувањата покажале дека третманот на однесувањето во здравството, кој вкдучува семејната терапија, е подобар третман кога е во комбинација со индивидуалниот третман па може да ги намали стапките на рецидивност, да ги намали психијатриските симптоми и да го намади стресот (Rowe, C. L., La Greca, A. M. and Alexandersson, A., 2010). 
Зависноста ги става членовите на семејството под голем стрес, ги попречува рутините и предизвикува вознемирувачки или дури и застрашувачки искуства. Како резултат на тоа, чиеновите на семејството развиваат нездрава стратегија за справување со проблемот, бидејќи се трудат да одржуваат рамнотежа во семејството. Семејната единица станува кревок и дисфункционален систем, и ова често ненамерно придонесува за зависноста, бидејќи семејството усвојува деструктивно однесување. Децата во семејството се особено погодени од зависност. Злоупотребата на супстанции како болест го прекинува нормалниот развој и води кон поголем ризик за физички, ментални и емоционални здравствени проблеми. Како пример се наведуваат проблемите на децата на зависниот родитед кои често имаат тешкотии во училиште, во социјалниот живот и веројатно е дека токму овие деца понатаму во животот ќе бидат можни зависници или ќе бидат скдони кон одредена зависност.

\section{1. Вдијание на здоупотреба на психотропни супстанции врз семеј- ствата}

Иако ефектите од здоупотреба на супстанции се раздикуваат врз основа на структурата на семејството, однесувањето на зависникот од дрога или алкохол сепак влијае врз семејната динамика на неколку начини (Substance Abuse Treatment And Family Therapy, 2015).

\section{Негативни емоции}

Како резултат на зиоупотреба на супстанции, чиеновите на семејството обично доживуваат негативни емоции како што се дутина, незадоволство, вознемиреност, загриженост, вина и непријатност.

Безбедност

Во некои случаи, безбедноста на другите членови на семејството може да биде ставена под веројатен ризик токму од здоупотреба на психотропните супстанци. Децата иди сопружниците, исто така, можат да почувствуваат потреба да добијат правна заштита поради страв од постапките на своите блиски.

\section{Одговорности}

Одредени членови на семејството наследуваат премногу одговорности иди одговорности кои не се соодветни за возраста. Ова може да предизвика децата или брачните другари да станат преоптоварени, вознемирени и огорчени.

\section{Комуникација}

Кога чиен на семејството здоупотребува дрога, комуникацијата во рамките на семејството често е негативна, а позитивната интеракција е 
многу ограничена. Покрај тоа, потребите, грижите и желбите на членовите на семејството, освен насилникот, може и најчесто се занемарени.

\section{Структура и границ̧и}

Домовите во кои постои здоупотреба на супстанции често имаат недостаток на структура со минимално вклучување на родителите и лабаво постоечки или непостоечки граници. Ова резултира со конфузија кај децата и негативно/несоодветно однесување. Родителите, браќата и сестрите, исто така, можат да усвојат можности за однесување што придонесуваат за злоупотреба на супстанции.

\section{Hezuparbe}

Во многу случаи, кога детето има проблем со злоупотреба на психотропни супстанции, родителите ќе негираат дека постои проблем. Ова може да биде затоа што тие не сакаат, не можат да се соочат со проблемот или едноставно не можат да го видат јасно.

Врски

Злоупотребата на супстанции создава оштетени односи кои може да продолжат преку повеќе генерации на семејството преку негативно моделирање на однесувањето. Освен тоа, зависниците од дрога или алкохол честопати се изолираат од другите членови на семејството и го поминуваат поголемиот дел од своето социјално време со другите зависници на супстанции во нивната затворена група.

Во семејства во кои еден или повеќе членови имаат проблем со злоупотреба на супстанции, лекувањето против здоупотреба на супстанции и семејната терапија може да се интегрираат за да се обезбедат ефективни решенија за повеќе проблеми. Советниците од социјалните служби и психотерапевтите од двете дисциплини имаат слична професионална обука. Следствено, интегрираните модели на третман служат како водич за пристапи за комбиниран третман особено кога станува збор за семејната терапија. Теоретската основа на голем број модели е дадена заедно со техниките и стратегиите што најчесто се користат. Низата потреби на кдиентот, повеќекратните семејни вдијанија и раздиките во обуката и приоритетите на советниците, заедно со тешката природа на повеќето проблеми со злоупотреба на психотропни супстанции, укажуваат на тоа дека полињата за третман на семејната терапија и третманот на зависноста треба тесно да бидат поврзани (Klarić, D., 2007). Интегрираните модели на семејни третмани ефикасно обезбедуваат услуги за зависниците и нивните семејства.

\section{2. Компатибидност на однесувањето на семејството со зависникот}

Проблемите најчесто се појавуваат кога некој мора да се прилагоди на дисфункцијата во семејниот систем. Соодветните однесувања се научени мисли, ставови и однесувања што доведуваат до занемарување на соп- 
ствените потреби и желби во корист на опсесивна загриженост за проблемите на некој близок. Соодветните однесувања вклучуваат:

Константна и опсесивна желба на членовите на семејството за пружање помош на членот - зависник од дроги.

Живеење во негирање за зависноста на некој член од семејството со цел да се избегнат последиците како на личен план, така и во самата општествена социјална средина.

Семејството реагира насилно или ирационално на настани поврзани со зависноста.

> Во семејството се јавува ниска самодоверба иста како и на зависникот како резуятат на запоставување на сопствените физички, духовни и емоционални потреби додека се фокусираат исклучиво на зависникот и неговите потреби.

Вклучување во сопственото нездраво однесување на останатите членови на семејството кое навидум помага во справување со реалноста.

> Признавање на проблемот и активно учество на останатите членови на семејството преку вклучување на зависникот во сите семејни активности, обврски и права кои произдегуваат од заедничкото живеење (Klein, G. 1999.).

Целта на психосоцијалната работа со зависниците од дрога преку семејниот тип на терапија е основа на рехабилитацијата и апстиненцијата, која воедно им дава можност на семејството, средината и зависникот како поединец да не чувствуваат отфрленост, односно да не бидат надвор од рамките на општествената колективна заедница.

\section{3. Придобивки од семејната терапија}

Постојат многу придобивки од семејна терапија, особено кога се користи во опцијата за лекување на одредена зависност. Семејната терапија им помага на членовите на семејната единица да заздрават и да закрепнат како група. Терапевтскиот амбиент обезбедува сигурен простор за сите да научат како да се прилагодат на заздравувањето на саканиот од зависност и ментална болест. Семејните тераписки сесии исто така се дизајнирани да им помогнат на членовите на семејството да направат специфични, позитивни промени за подобрување на домашната средина, како и заздравување на односите во рамките на семејната единица. Семејната терапија обично ги вклучува зависникот од психотропните супстанции и најмалку уште еден член од семејството. Ова може да биде сопружникот, родителот, брат иди сестра или некој друг кој има близок однос со лицето што се лекува.

Голем број на истражувања го демонстрираат позитивното вдијание што семејството може да го има врз закрепнувањето на членот на семејството од зависност. Токму многу автори сметаат дека без семејна тера- 
пија при здоупотреба на дроги не е ни можно издекување и притоа ги истакнуваат многубројните придобивки од вклучувањето на семејството во закрепнувањето (Beavers, R., \& Hampson, R. B., 2000).

- Поддржување на зависникот преку мотивираност за време на третманот,

> Вербално учење за поимот зависност и ефектите врз семејството, како и разбирање на тоа како семејниот третман функционира и што да се очекува од тој пристап за време на терапијата и по завршувањето,

Овозможување на членовите на семејството да ги изразуваат чувствата и грижите и да поставуваат прашања во врска со зависноста на саканиот,

$>$ Понуда на саканиот висок степен на соодветна поддршка по третманот односно ослабување на чувствата на страв, гнев, стрес и конфузија поврзани со зависноста,

> Можност за членовите на семејството да развијат вештини и стратегии за да му помогнат на својот близок да остане на патот кон закрепнување,

> Подобрувања во семејните комуникациски вештини,

$>$ Можност да се решат сите прашања поврзани со менталното здравје во рамките на семејниот систем, како што се депресија или анксиозност, што може да ја попречи семејната комуникација и да придонесе за рецидивно однесување на зависникот.

Според социјалните работници во косоработка со психолозите од соодветните центри, семејната терапија покажува позитивни резултати за проблемите со употребата на супстанции и коегзистирачки нарушувања како што се депресија, занемарување, невработеност и други видови семеен конфликт. Кога семејната терапија се бира како најсоодветен модел за борба со зависноста особено кога е тоа можно, односно кога семејството постои и има вистинска желба и потреба да се надмине конфликтната ситуација која е реално многу тешка како за останатите членови, така и за самиот зависник, а тоа подразбира одредени очекувања и претпоставки (Rowe, C. L., La Greca, A. M. and Alexandersson, A., 2010):

- Вклучување на семејството. Семејната терапија за зависност обично започнува откако корисникот ќе влезе во овој облик на третман за надминување на злоупотребата на психотропните супстанции и притоа постигнува напредок. Ова значи дека станува збор за макотрпен, комплексен третман на подолг временски рок од неколку недели до неколку месеци, па и години. Вообичаено го вклучува клиентот во третман на злоупотреба на дроги и најмалку уште еден член од семејството. Ова може да биде член на непосредно, проширено, семејство или друго лице кое е значително блиско со клиентот. 
Животни вештини. За време на терапијата, советникот има обврска да им помогне на членовите на семејството додека стекнуваат нови вештини, нови начини на животен стил и притоа сите заедно треба да научат како да ги применуваат. Ова помага да се создаде поздрава интеракција во домашни услови која ја подобрува целокупната околина. Советниците, исто така, ги учат чденовите на семејството како да комуницираат поефикасно и да се однесуваат на начини кои го поддржуваат заздравувањето на кдиентот, наместо да го попречуваат тоа.

* Промени во однесувањето. Управувањето со вонредни состојби односно релапс на зависникот, апстиненцијални кризи, депресивни кризи исто така се користи во рамките на семејна терапија за да му се помогне на зависнокот додека тој или таа развива цели во однесувањето кои поттикнуваат апстиненција од секаква употреба на супстанции. Ова го подобрува напредокот и помага да се решат основните проблеми и да се надминат оштетените односи во семејството.

* Поставување цел. Од членовите на семејството се бара да постават цели поврзани со улогите што ги играат во рамките на семејната единица. На пример, родителите поставуваат цели кои се поврзани со нивните родителски улоги, браќата и сестрите поставуваат цели што се поврзани со тоа што се брат или сестра и така натаму. Овие цели се разгледуваат за време на секоја сесија, и семејната терапија помага на комплетниот семеен округ, а не само на зависникот. Целите се основниот мотиватор кој овозможува исцртување на соодветен пат кон надминување на проблемот и болеста и обезбедува желба да се стигне до крајот на патот.

\section{4. Опасност од неприфаќање на терапијата од страна на чден на се- мејството}

Во некои случаи, член од семејството можеби не е подготвен да учествува во овој вид на терапија. Ова често се должи на страв, скептицизам дека советувањето нема да направи раздика, иди чиста исцрпеност од тековните напори. Некои, исто така, може да се загрижени за ред многу работи како што е стравот од заплеткување на тој член во терапија која ќе го опфати и неговото однесување, потоа опасноста од соочување со тешки проблеми со кои не би сакале да се соочаат. Семејната терапија значи дека и другите членови од семејството се вклучени во психосоцијалната работа со зависникот и тие треба да се соочат со наводно откривање на семејни тајни како здоупотреба, зависност или нелегални активности. Доколку се случи тоа, корисно е индивидуата да се сретне со советникот на индивидуална основа за да ги објасни неговите грижи, да ги разгледа намерите и придобивките од семејното советување, како и да го поттикне учеството. На крајот на краиштата, одлуката за учество мора да се изврши добро- 
волно, но дополнителното образование и охрабрување од стручно дице за зависности може да помогне да се убедат неподготвените чденови на семејството да ја прифатат семејната терапија. Реално може да биде многу тешко да се придобијат неподготвените членови на семејството кои би се вклучиле во третманот. Главна улога во ваквите случувања имаат психоедукативните работници и мотивационото интервјуирање на тие членови кои можат да помогнат да ослабне отпорот кај овие членови.

Во психосоцијалната работа постојат како облик и психоедукативни работилници кои ја образдожуваат терапијата и ја даваат важноста и далекусежните придобивки од вкдучувањето на семејството во закрепнувањето. Мотивационото интервјуирање може да му помогне на чиенот на семејството да работи преку амбивалентност кон закрепнување и да им помогне да ги идентификуваат сопствените мотиви за промена, односно да ги разбере и прифати целите на овој облик на семејна терапија во случај на зависност од дроги.

\section{5. Целите на семејната терапија за зависности}

Според службите за ментално здравје и психосоцијална работа, постојат две главни цели на семејна терапија за зависност.

1. Обезбедување корисна поддршка за зависникот во периодот на апстиненција и лекување. Семејната терапија ги намалува шансите за повторно навраќање кон зависноста, помага во развојот и одржувањето на позитивните промени во однесувањето и ставот и промовира долгорочно закрепнување на индивидуата во третманот при здоупотреба на овие супстанции.

2. Потоа е претпоставена опцијата како што е подобрување на емоционалното здравје на семејството како целина. Терапијата им помага на членовите на семејството да воспостават доверба и да промовираат прошка за минатото однесување и кај зависниците, но и кај членовите на семејството. Исто така може да обезбеди мир и да ги реши конфликтите или чувствата на гнев, фрустрација и тага. Дополнително, семејната терапија има за цел колку што е можно да се намалат ефектите од тековната криза и апстиненцијалните кризи кои следуват и ги охрабрува учесниците да излезат од негативни емоции (Beavers, R., \& Hampson, R. B., 2000).

\section{6. Опасност од рецидивно посегнување кон психотропните суп- станци}

Здравјето, домашната средина и заедницата се камен-темелник на животот во закрепнувањето, но важно е да се разбере дека неуспесите, кои релативно постојат се однесувања кои може да доведат до рецидивно однесување, се нормален дел од заздравувањето. Стапките на рецидиви за зависност се слични на оние за други хронични заболувања, како што се 
срцеви заболувања и дијабетес. Помеѓу 40 и 60 проценти од дицата кои заздравуваат ќе рецидираат во одреден момент. Важно е за поединецот во закрепнувањето и членовите на семејството да сфатат дека релапсот и другите пречки не се крај на процесот на одвикнување од зависноста. Релапсот сега се смета за можност да се оцени планот за закрепнување и да се одреди што предизвикало вакво однесување, а потоа да се преземат чекори за развивање препознавање на тригерите што довеле до релапс (Веаvers, R., \& Hampson, R. B., 2000).

Ауѓето кои ги сметаат неуспесите како дичен неуспех, најверојатно ќе ги игнорираат сите позитивни придобивки направени во закрепнувањето и може да чувствуваат дека трезноста, односно неконсумирање на дрогите е премногу тешко да се постигне. Спротивно на тоа, оние кои ги гледаат неуспесите како катадизатор за повторно оценување на планот за закрепнување, идентификување на причините за рецидивното однесување што довело до неуспех, најверојатно, ќе се вратат на патот кон закрепнување посилно од порано, со поголема решителност и мотивација за постигнување долгорочна апстиненција. Се покажало дека вклучувањето на семејството во третманот и заздравувањето помага да се спречи релапсот, но реално повторното посегнување кон дрогата е секогаш возможно.

Познавањето на фазите на релапсот и знаците поврзани со секоја фаза може да им помогне на членовите на семејството да ја препознаат претстојната пречка, да му помогнат на својот член да избегне рецидивно однесување и со тоа да се добие поддршка што е потребна за да се вратат на вистинскиот пат.

\section{Питература:}

BARLOW, D. H. (2010). Negative effects of psychological treatments: A perspective. American Psychologist, 65, 1, 13-20.

BEAVERS, R., \& HAMPSON, R. B. (2000). The beavers systems model of family functioning. Journal of Family Therapy, 22(2), 128-143.

KLARIĆ, D. (2007.): Droga - nerješiv problem; priručnik za edukatore, Dvotočka, Zagreb.

KLEIN, G. (1999.): Sources of power: how people make decisions, MIT press.

Rowe, C. L., La Greca, A. M. AND AleXandersson, A. (2010), 'Family and individual factors associated with substance involvement and PTS symptoms among adolescents in greater New Orleans after Hurricane Katrina', Journal of Consulting and Clinical Psychology 78, pp. 806-817.

Substance Abuse Treatment And Family Therapy, (2015), U.S. DEPARTMENT OF HEALTH AND HUMAN SERVICES Substance Abuse and Mental Health Services Administration Center for Substance Abuse Treatment 